Special Issue: Agricultural Productivity and Sustainability Improvement in Tropical Region

\title{
On the Way to Sustainable Peat-Free Soil Amendments
}

\section{Zane Vincevica-Gaile ${ }^{1}$, Karina Stankevica ${ }^{1}$, Maris Klavins ${ }^{1}$, Roy Hendroko Setyobudi ${ }^{2}$, Damat Damat ${ }^{3 *}$, Praptiningsih Gawawati Adinurani ${ }^{4}$, Lili Zalizar, Muhammad Zul Mazwan ${ }^{6}$, Juris Burlakovs ${ }^{7}$, Didiek Hadjar Goenadi", ${ }^{8,9}$ Rista Anggriani ${ }^{3}$ and Aamir Sohail ${ }^{10}$}

${ }^{1}$ Department of Environmental Science, Faculty of Geography and Earth Sciences, University of Latvia, Jelgavas Street 1, Riga LV-1004, Latvia, Indonesia; ${ }^{2}$ Department of Agriculture Science, Postgraduate Program, University of Muhammadiyah Malang, Jl. Raya Tlogomas No 246, Malang 65144, East Java, Indonesia; ${ }^{3}$ Department of Food Technology, Faculty of Agriculture and Animal Science, University of Mubammadiyah Malang, Malang 65144, Indonesia; ${ }^{4}$ Department Agrotechnology, Faculty of Agriculture, Merdeka University of Madiun, Jl. Serayu No.79, Madiun 63133, East Java, Indonesia; ${ }^{5}$ Department of Animal Science, Faculty of Agriculture and Animal Science, University of Muhammadiyah Malang, Malang 65144, Indonesia; ${ }^{6}$ Department of Agribusiness, Faculty of Agriculture and Animal Science, University of Mubammadiyah Malang, Malang, 65145, Indonesia; ${ }^{7}$ Chair of Rural Building and Water Management, Estonian University of Life Sciences, 51014 Tartu, Estonia; ${ }^{8}$ Indonesian Research Institute for Biotechnology and Bioindustry, Jl Taman Kencana No. 1 Bogor 16128, West Java, Indonesia; ${ }^{9}$ Indonesian Inventor Association, Jl. Rawa Bambu Raya No. 17 A Pasar Minggu, Special Capital Region of Jakarta 12520, Indonesia; ${ }^{10}$ University of Bolton, A676 Deane Rd, Bolton BL3 5AB, UK.

Abstract | Increasing global population and urbanization demands enhanced food and feed crop production, but due to several reasons, the areas of fertile agricultural lands are reducing worldwide. The market of growing substrates, soil amendments, and improvers still is based on peat extraction and processing. Due to peat's fossil origin, it can be considered environmentally unfriendly and unsustainable. Seeking peat-substituting materials is of crucial importance on a global scale and may become a vitally significant assignment for future generations. The necessity for peat-free soil amendments is also directed by the targets of circular economy and environmental sustainability goals, leading to reducing or abandoning the use of fossil resources and paying attention to waste utilization as secondary raw material. This paper aims to discuss general features of peat-free soil amendments as well as provide efforts into the use of secondary raw materials such as biomass ashes for the elaboration of peat-free soil-improving products. As a case example, may serve a description of the peat-free product made by rotary drum granulation from biomass fly ashes (energy production waste) and local freshwater sediments in a mass ratio mixture of 67:100, optimally applicable for soil improvement at a rate of $50 \mathrm{~g} \mathrm{~L}^{-1}$. Besides, regional opportunities in Indonesia and Latvia are referred. It was concluded that peat-free soil amendment elaboration can be better implemented on a regional scale after assessing agricultural needs, soil specifics, and available raw material variety applicable as ingredients in soil-improving products.

Received | November 01, 2021; Accepted | December 15, 2021; Published | December 30, 2021

*Correspondence | Damat Damat, University of Muhammadiyah Malang, Malang 65144, Indonesia; Email: damatumm@gmail.com

Citation | Vincevica-Gaile, Z., K. Stankevica, M. Klavins, R.H. Setyobudi, D. Damat, P.G. Adinurani, L. Zalizar, M.Z. Mazwan, J. Burlakovs, D.H. Goenadi, R. Anggriani and A. Sohail. 2021. On the way to sustainable peat-free soil amendments. Sarbad Journal of Agriculture, 37(Special issue 1): $122-135$.

DOI | https://dx.doi.org/10.17582/journal.sja/2021.37.s1.122.135

Keywords | Bio-based soil improver, Biomass ashes, Organic freshwater sediments, Peat-free amendment, Soil improvement 


\section{Introduction}

\section{The need for peat replacement}

The growth of the global population and 1 urbanization leads to increased demand for water, food, and feed, which, in turn, requires larger and larger areas of fertile agricultural lands (Mohamed et al., 2016; Shah; et al., 2021). At the same time, large agricultural areas covered by monocultures such as oil palms (Elaeis guineensis Jacq.), rubber (Hevea brasiliensis Müll.Arg.), maize (Zea mays L.), sugarcane (Saccharum officinarum L.), and fuel crops such as rapeseed (Brassica napus L.) take up space instead of multicultural food crops resulting in adverse impact leading to loss of soil fertility, increased soil salinity, erosion, depletion, and decreased environmental quality and biodiversity soil depletion (Ghadeer and Al Khalil, 2019; Guillaume et al., 2016; Mohamed et al., 2016; Putra et al., 2020; Schiefer et al., 2016; Vanham et al., 2021). In particular, several experts have discussed the problem of soil fertility in oil palms in Indonesia (Herry et al., 2020; Hsiao-Hang et al., 2016; Petrenko et al., 2016; Shahputra and Zen, 2018), while other scientists (Hartemink, 1964; Kusumawati et al., 2020; Putra et al., 2020) have discussed and reported about soil degradation in sugarcane plantations in Indonesia.

Furthermore, climate change predictions point at more frequent environmental instabilities such as extensive heat resulting in dryness and natural fires, excessive precipitation leading to floods, sudden and intense cold bringing crop yield loss. It can be said convincingly that warmer climate zones will be affected much more severely than the lands located in temperate climatic conditions (Ghadeer and AlKhalil, 2019; Gruda, 2019; Nizami et al., 2020; Schiefer et al., 2016). Food crop cultivation in controlled environment conditions and soil-less systems is increasing and can solve only a part of the problems. Instead of natural soil, various growing mediums are used, or soilless plant growth is provided (Bar-Tal et al., 2019; Gruda, 2019). For sustainable management of agricultural/ arable lands systemic approach must be implemented that becomes an everyday practice and is established at the governmental level directing the economic systems altering from the linear economy to circular approach where waste becomes a value (Abdullah et al., 2020; Setyobudi et al., 2019; 2021; Sadik et al., 2021; Zakaria et al., 2020). Limitations of global resources and dependence on fossil resources lead to broader utilization of secondary resources, meaning reuse and recovery of materials and reducing disposed waste, more or less in every economic sector (Chojnacaka et al., 2020; Millar et al., 2019; Setyobudi et al., 2018; Yandri et al., 2021). In this aspect, the need to develop bio-based soil-improving products is driven by the global trends of environmental sustainability and circular economy (Abdullah et al., 2020; Adinurani et al., 2017; Chojnacaka et al., 2020; Klavins and Obuka, 2018; Millar et al., 2019; Urbinati et al., 2017; Vincevica-Gaile et al., 2019 and 2021b): i) to expand and increase reuse of biodegradable industrial waste; ii) to exploit renewable natural resources instead of non-renewable (fossil) resources; iii) to pay greater attention to the use of locally available resources.

The market of growing media (growth substrates), soil improvers, and amendments still are greatly based on peat extraction and processing and, due to that, can be considered as environmentally unfriendly as a fossil resource is utilized in significant amounts (Carlile et al., 2015; Jürgen et al., 2017; Schmilewski, 2009). Peat is an economically significant yield of peatlands, generally recognized as swamps, bogs, marshes, wetlands, and mires, globally covering more than $4 \times 10^{6} \mathrm{~km}^{2}$. Furthermore, the Baltic states (Latvia, Lithuania, Estonia) are among the worldwide leaders in peat extraction (Index Mundi, 2013; Tanneberger et al., 2017), but Indonesia holds almost $25 \%$ of the world's total tropical peatland areas (Osaki, et al., 2016; Rieley and Page, 2016; Vincevica-Gaile et al., 2021b; $\mathrm{Xu}$ et al., 2018). Also, studies on $\mathrm{CO}_{2}$ emissions from peat extraction have revealed that Europe highly depends on this resource (Taparia et al., 2021; Quintero et al., 2015), nevertheless, the target of the European Green Deal is climate-neutral Europe by 2050 (EC, 2019) and it should serve as a step towards global climate change mitigation. It is the reason why at the national level, several countries are starting to reduce peat utilization and are looking for new, more sustainable substituting materials. The problem can be solved by implementing new strategies in the development of growing media, soil conditioners, or amendments based on material cycling and utilization of secondary resources instead of primary ones (Carlile et al., 2015; Chojnacka et al., 2020; Nurzakiah et al., 2013; Stankevica et al., 2013).

The necessity for peat-free soil amendments and substrates is directed by the targets of circular economy and goals of environmental sustainability such as increasing recycling and reuse of renewable natural 


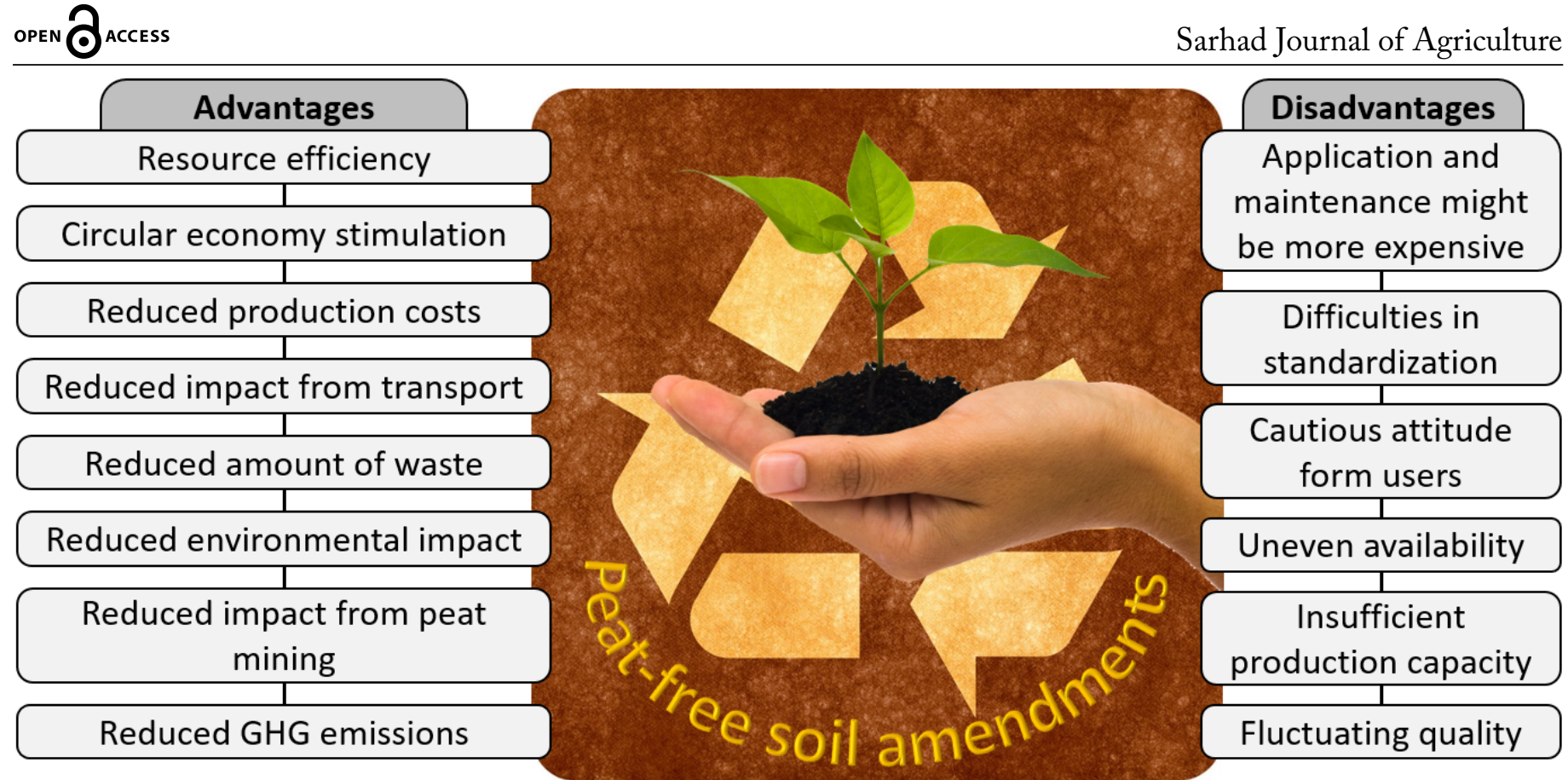

Figure 1: Advantages and disadvantages of peat-free soil-improving amendments (EC, 2018; EUBIA, 2021).

resources instead of fossil ones (such as peat is), decreasing global greenhouse gas emissions by using local resources avoiding long transportation routes (Chojnacka et al., 2020; Klavins and Obuka, 2018; Pursula et al., 2018).

This paper aims to discuss the features of peatfree soil amendments and provide insight into the efforts in the elaboration of granulated peat-free soil amendment using organic-rich freshwater sediments - sapropel, in a mixture with industrial waste from energy production - biomass ashes as a case example.

\section{Features of peat-free soil amendments}

Several goals need to be achieved by implementing sustainable soil management in agriculture, e.g., positive nutrient budget, reduction of erosion and pollution, increased carbon content, presence of beneficial microorganisms, optimal water supply, and infiltration (Chojnacka et al., 2020; Schiefer et al., 2016; Shahen, 2016). Soil improvers are applied to reach one or more of these goals if the natural environmental state of soil is damaged. The general term of a soil improver or amendment is referred to a 'substance/material applied periodically to the soil in situ to maintain or improve its physical, and/or chemical and/ or biological properties or activity, but excluding typical liming agents (EC, 2017; EC, 2018). Conventional soil improvers include peat and its products and various mineral-based and synthetic fertilizers. An organic soil improver is a mixture containing carbonaceous materials with the primary function to increase soil organic matter content; furthermore, in this case, peat is not assessed as an organic constituent (EC, 2017).

As an alternative to conventional soil-improving amendments, the term 'bio-based' or 'peat-free' soil improver is attributed to the materials such as compost, mulch, and particular sludge. Furthermore, bio-based/peat-free soil improvers can contain secondary raw material derived from various waste streams (Chojnacka et al., 2020; EC, 2017; Taparia et al., 2021). Motivation to develop peat-free soilimproving amendments is based on a sustainable bioeconomy approach, also grounded in the ideas of the European Green Deal, such as moving to 'zero waste' production, resource efficiency, ensuring the quality of the environment (Awasthi et al., 2021; EC, 2019). Advantages prevail over disadvantages, especially in the long-term (Figure 1).

Deeper comprehension and environmental awareness step in step with stricter regulations on energy efficiency and environmental pollution are acting as driving forces. The struggle to attain the compromise between the goals of the environment and economics is going on without ceasing (Nizami et al., 2020; Sadiq et al., 2019). Globally growing waste streams must be reduced and turned to create beneficial outcomes. Extraction and utilization of primary resources should be reduced; instead, generated waste can be utilized as secondary raw materials, depending on the origin and character, can be applied to improve soil state, gravimetric properties, physical-chemical properties, 


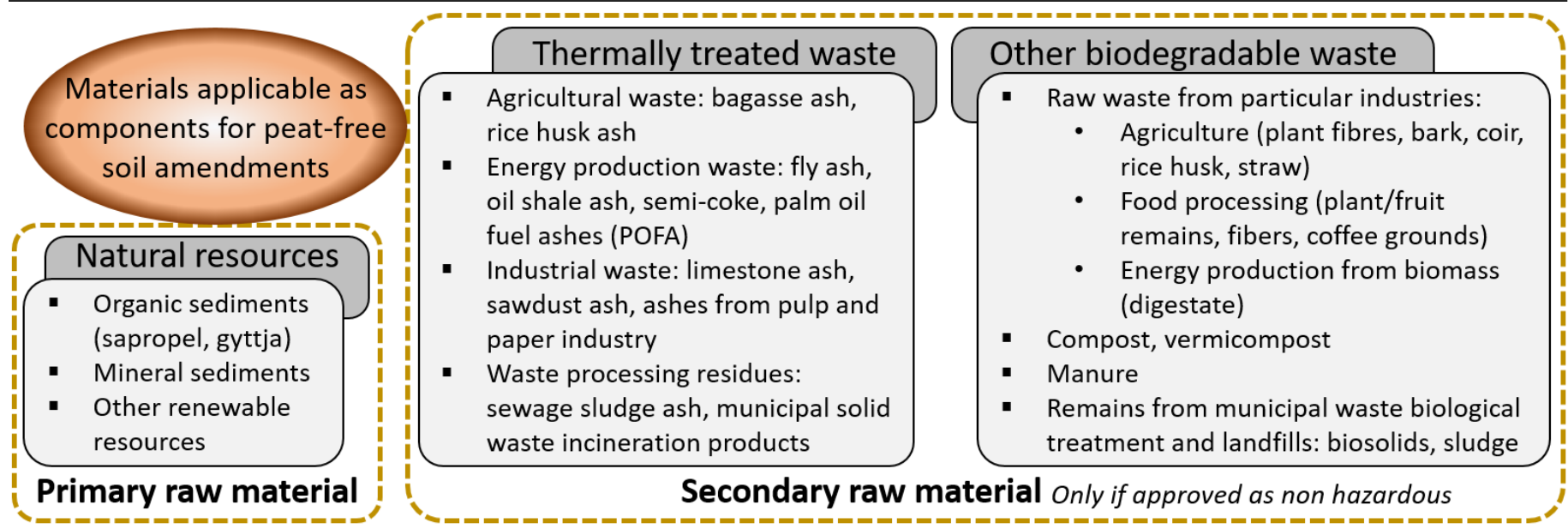

Figure 2: Examples of materials applicable as constituents of peat-free soil amendments.

as well as fertility, leading to circular economy implementation in agricultural practices and urban gardening (Coenen et al., 2015; Urbinati et al., 2017). The choice of sustainable materials (Figure 2) is vast, but the problem remains in the elaboration of 'the perfect composition' in terms of applicability, efficiency, cost-effectiveness.

Environmental concern must be considered when selecting components from the list of secondary raw materials to be used for the elaboration of peat-free soil-improving amendments.

\section{Case Example in Elaboration of Peat-Free Soil Amendment}

Choice of biomass ashes as appropriate raw material: Biomass ashes are the primary waste material generated during the energy (heat and power) production at cogeneration plants (Masto et al., 2015). Biomass ashes (fly and bottom ashes), if securely and adequately applied into the soil, may play a significant role in plant nutrition and soil improvement as well as nutrient cycling favorable for agriculture, gardening, and greenery landscaping purposes (Anggarani et al., 2021; Bhattacharya and Chattopadhyay, 2002; Jain et al., 20212; Romdhane et al., 2021). The composition of wood ashes incorporates a mixture of chemical elements mainly in the form of oxides, hydroxides, carbonates, and silicates (Demeyer et al., 2001). Biomass ashes are useful to increase the soil $\mathrm{pH}$ and supply the soil with nutrients such as $\mathrm{Ca}, \mathrm{K}, \mathrm{Mg}$, and $\mathrm{P}$ (Chirenje and Ma, 2002; Prisca et al., 2021; Ram and Masto, 2014; Samadhi et al., 2019; Sparrevik et al., 2014), but they are depleted in nitrogen and, therefore, cannot be used as a general soil improver or fertilizer (Röser et al., 2008). However, specific security measures have to be applied in the use of biomass ashes as some toxic and possibly toxic elements ( $\mathrm{As}, \mathrm{Co}, \mathrm{Cu}, \mathrm{Ni}, \mathrm{Pb}$, and $\mathrm{Zn}$ ) may be present and can be toxic to plants as well as are of environmental concern (Masto et al., 2015; Perkiömäki, 2004; Utami et al., 2019).

Biomass ashes have been used in this project because it was relatively easy to obtain in large quantities due to the waste from the boiler power plant. However, several experts stated that biochar is more effective as a soil enhancer (Deenik et al., 2011; Martinsen et al., 2015; Nur et al., 2021; Omil et al., 2013; Puvan et al., 2021; Santalla et al., 2011; Titiek et al., 2011; Zaffar et al., 2017) and also in suppressing greenhouse gases (Atanu and Lal, 2013; Kamman et al., 2017).

Meanwhile, in Indonesia, potential sources of ashes that are commonly used for soil improvement are derived from palm oil processing and sugar factories. The power plant boilers in the two factories use solid waste, namely palm fiber, and shells, as well as bagasse in the sugar factory. Another source of ashes in oil palm plantations is empty fruit bunches. This organic material or its ashes is used internally as a substitute for potassium fertilizer based on the recycling principle (Arfiana et al., 2021; Herry et al., 2020; Kusumaningtyas et al., 2015).

Another source of biomass ashes in Indonesia is a waste of bioethanol factories (based on molasses). For example, a bioethanol factory in East Java, Indonesia, produces $80000 \mathrm{~kL} \mathrm{yr}^{-1}$ with liquid waste amounts of $1.2 \times 10^{6} \mathrm{~L}$ of vinasse $\mathrm{d}^{-1}$. This vinasse is utilized in three products, namely, (i) boiler vinasse fuel capable of producing $56 \mathrm{t}$ of steam which can be converted into 4.9 MW of electricity that is used for $90 \%$ of the electricity needs of the bioethanol plant; (ii) vinasse is 2021 | Volume 37 | Special Issue 1 | Page 125 
burned into ashes which are granulated with binder molasses into solid organo-mineral fertilizer (OMF), especially as potassium fertilizer; (iii) liquid vinasse is mixed in a mixture of organic materials (including filter cake, sugar factory waste). The mixture of materials is dried in the greenhouse ( $3 \mathrm{ha}$ ), granulated, and then sold as organic fertilizer (Agusta et al., 2021; Brotodjojo and Dyah, 2016; Gurgel et al., 2015; Utami et al., 2021). The unit production of potassium fertilizers and organic fertilizers is estimated at $10500 \mathrm{t} \mathrm{yr}^{-1}$ and $10000 \mathrm{t} \mathrm{yr}^{-1}$, respectively (Molindo, 2021).

Several scientific groups (Dirbeba et al., 2019a; 2019b; Gurgel et al., 2015; Kamalia et al., 2021; Kusumaningtyas et al., 2015; 2020) have studied the process of solid OMF vinasse base. While others (Anas et al., 2007; Kusumaningtyas et al., 2017) have reported the positive impact of OMF vinasse based on the productivity of tomatoes (Solanum lycopersicum L.) and sugarcane.

\section{Case study in Latvia}

A prototype of peat-free soil amendment formulation was developed at the Department of Environmental Science, University of Latvia, located in North-East Europe. Local materials and industrially produced secondary resources were selected to elaborate peatfree products applicable for soil improvement.

Biomass ashes for the elaboration of peat-free soil amendment were collected at commercial power plants in Lithuania and Latvia, assessing fly ashes among the ash types as the most appropriate. Biomass fuel used in these cogeneration plants consisted of coniferous softwood chips with a negligible admixture of deciduous (< $5 \%$ ) and herbaceous (< $1 \%)$ biomass, or a variety of forest wood waste chips. Fullscale characterization was performed to estimate descriptive parameters of ashes such as dry matter, volatile matter, fixed carbon, gravimetric water and dry matter, bulk density, solid density, as well as elemental content and element bioavailability. Complete details on the investigation, including methodology and results, of biomass ashes, can be found in an openaccess dataset (Vincevica-Gaile et al., 2021a).

Specific organic-rich sediments were used as a natural adhesive, providing organic matter into peatfree soil amendment formulation. Organic-rich freshwater sediments - sapropel - are formed mainly in eutrophic freshwater lakes. Sapropel primarily consists of the remains of water plants, plankton, and benthic organisms transformed by microorganisms in a mixture with mineral components supplied from the water body basin. Various types of sapropel usually contain a high amount of organic matter (15\% to $90 \%)$. Fresh sapropel is characterized as a mudlike, colloidal substance, occurring at the bottom of continental water bodies, with characteristic finely dispersed and plastic structure. Sapropel is assessed as a strategical resource in such countries as Latvia, Lithuania, Estonia, Belarus, Russia, where it can be found in industrially significant amounts in eutrophic lakes and bogs. For example, in Latvia, after geological surveys in 1600 freshwater lakes, sapropel deposits were estimated at $930 \times 10^{6} \mathrm{~m}^{3}$. Already historically, sapropel has been exploited as a soil amendment, but due to the variability of physical-chemical properties among its types and classes seeking new sustainable and cost-effective utilization ways is ongoing. Application possibilities of sapropel are not limited only to agriculture and soil improvement. However, it can be used as a raw material also in the construction industry, chemical industry, and medical and pharmaceutical industry (e.g., applied as healing mud in balneology) (Stankeviča, 2020).

Sapropel samples for the elaboration of soil amendment were extracted from freshwater lakes in Latvia and Lithuania by coring using a $10 \mathrm{~cm}$ diameter peat sampler with a $1.0 \mathrm{~m}$ long camera according to the procedure (Stankevica et al., 2020). Sapropel type and the class were identified according to the classification (Stankeviča, 2020). Sapropel of biogenic class, organogenic order, and peaty, green algae or cyanobacteria type was selected to elaborate a peat-free soil amendment.

Among the methods that were applied to investigate sapropel samples, the most important were loss-onignition (LOI) for estimating the content of moisture, organic matter, ash, and carbonates (Stankevica et al., 2020), as well as chemical composition analysis for trace and major element detection (VincevicaGaile and Stankevica, 2018) implemented by atomic absorption spectrometry (AAS) (AANAYLST 200, Perkin Elmer) and inductively coupled plasma mass spectrometry (ICP-OES) (iCAP 7000, Thermo Scientific).

\section{Methodology: Ash-sapropel granulation}

Peat-free soil amendment from biomass ashes in a 
mixture with sapropel as a natural binder was elaborated by applying extrusion and rotary drum granulation resulting in two types of granules - extruded and spherical (Rodrigues et al., 2017; Vincevica-Gaile et al., 2019). Wet granulation was chosen as an appropriate method due to several advantages as it is a size-enlargement process applied in many industrial fields, such as pharmaceuticals, nutraceuticals, zootechnicals, to improve the flowability and compressibility properties of powders (De Simone et al., 2018). Screened by sieving $(1500 \mu \mathrm{m})$, biomass fly ashes were used for granulation together with homogenized sapropel, which was gradually admixed to gain the best consistency applicable for granulation. Mixing was performed using an anchor type mixer (KM3350, Clatronic) at $50 \mathrm{rev} \mathrm{min}^{-1}$. Granulation was implemented using an elaborated laboratory-scale granulator, being successfully used for the granulation of clay-containing mixtures (Shishkin et al., 2017).

Broad physical-chemical characterization of granules was performed, including bioavailability detection of trace and major elements, as well as testing the plant and soil response to the addition of granules into the substrate.

\section{Remarks on results: Characterization of ash-sapropel granules}

Experimental tests revealed that the most promising for granulation with biomass ashes was peaty sapropel and its characteristic parameters were as follows: $\mathrm{pH} 7.6$, moisture $92 \%$, organic matter $81 \%$, ash content $19 \%$, bulk density $1066 \mathrm{~kg} \mathrm{~m}^{-3}$. In turn, biomass ashes were represented by the following parameters: $\mathrm{pH} 12.6$, moisture $1 \%$, volatile matter $8.8 \%$, fixed carbon $28 \%$, ash content $62 \%$, bulk and solid density - 370 and $2430 \mathrm{~kg} \mathrm{~m}^{-3}$, respectively, porosity $0.84 \mathrm{~m} \mathrm{~m}^{-3}$. After granulation trials and application of the bisection method to detect the best ratio of the composition (Green and Southard, 2019), the mass ratio $67: 100$, respectively biomass ashes to sapropel, was assessed as the most suitable. Application of rotary drum granulation allowed deriving granules characterized with increased mechanical strength and bulk and apparent density higher in comparison with granules derived by the process of extrusion (Table 1 ).

Rotary drum-derived granules inhered greater mechanical strength (by $10 \%$ to $25 \%$ ) and density (by $25 \%$ to $50 \%$ ) if compared to extruded granules. Water absorption of granules was variable and mainly influenced by the properties of used sapropel type reaching up to $200 \%$ for extruded granules. Besides, extrusion granules are characterized by lower moisture content.

Table 1: Average values characterizing ash-sapropel granules.

\begin{tabular}{|c|c|c|c|}
\hline \multirow[t]{2}{*}{ Parameter } & \multirow[t]{2}{*}{ Unit } & \multicolumn{2}{|c|}{ Type of granules } \\
\hline & & $\begin{array}{l}\text { Extruded } \\
\text { (cylindrical) }\end{array}$ & $\begin{array}{l}\text { From drums } \\
\text { (spherical) }\end{array}$ \\
\hline Diameter & $\mathrm{cm}$ & 0.8 & 0.8 \\
\hline Height & $\mathrm{cm}$ & 2.1 & 0.8 \\
\hline Volume & $\mathrm{cm}^{3}$ & 1.1 & 0.4 \\
\hline Material column* & $\mathrm{m}$ & $82 / 27 / 7$ & $32 / 11 / 3$ \\
\hline Density $^{* *}$ & $\mathrm{~kg} \mathrm{~m}{ }^{-3}$ & $137 / 280$ & $393 / 560$ \\
\hline Compressive strength & $\mathrm{MPa}$ & 0.110 & 0.112 \\
\hline Specific surface area & $\mathrm{m}^{2} \mathrm{~g}^{-1}$ & 178 & 70 \\
\hline Water absorption & $\%$ & 198 & 67 \\
\hline
\end{tabular}

It was assessed that there might occur differences in physical parameters among the types of granules due to the technical peculiarities of the granulation process, e.g., spherical granules are harder, but with lower porosity and lower content of moisture, thus they can be more convenient for transporting and storage at industrial scale. The size of granules can be adjusted regarding the potential application target. The composition of granules can be adjusted regarding necessary outcome properties. Properties and moisture content of ingredients used for granulation are the main limiting factors for the quality of the derived product. $\mathrm{pH}$ measurements revealed that the use of biomass ashes for the production of granules in a mixture with sapropel could favorably lead to a decrease of alkaline character.

The total content of elements revealed the abundance of $\mathrm{Ca}, \mathrm{K}, \mathrm{Mg}, \mathrm{Mn}, \mathrm{P}, \mathrm{Al}, \mathrm{Fe}$, and $\mathrm{Na}$ in granules, while other elements were detected in smaller amounts (Figure 3). Bioavailability of elements was assessed, considering their concentration in water or weak acid solution versus residual fraction.

Quantitative analysis revealed that the majority of elements (except $\mathrm{K}, \mathrm{Ca}, \mathrm{Mg}, \mathrm{Na}, \mathrm{Li}$, and $\mathrm{Sr}$ ) were bound in a residual fraction, which indicates their low solubility and slow release at ambient environmental conditions. However, a change of $\mathrm{pH}$ could affect the release of elements, whereas non-essential and 


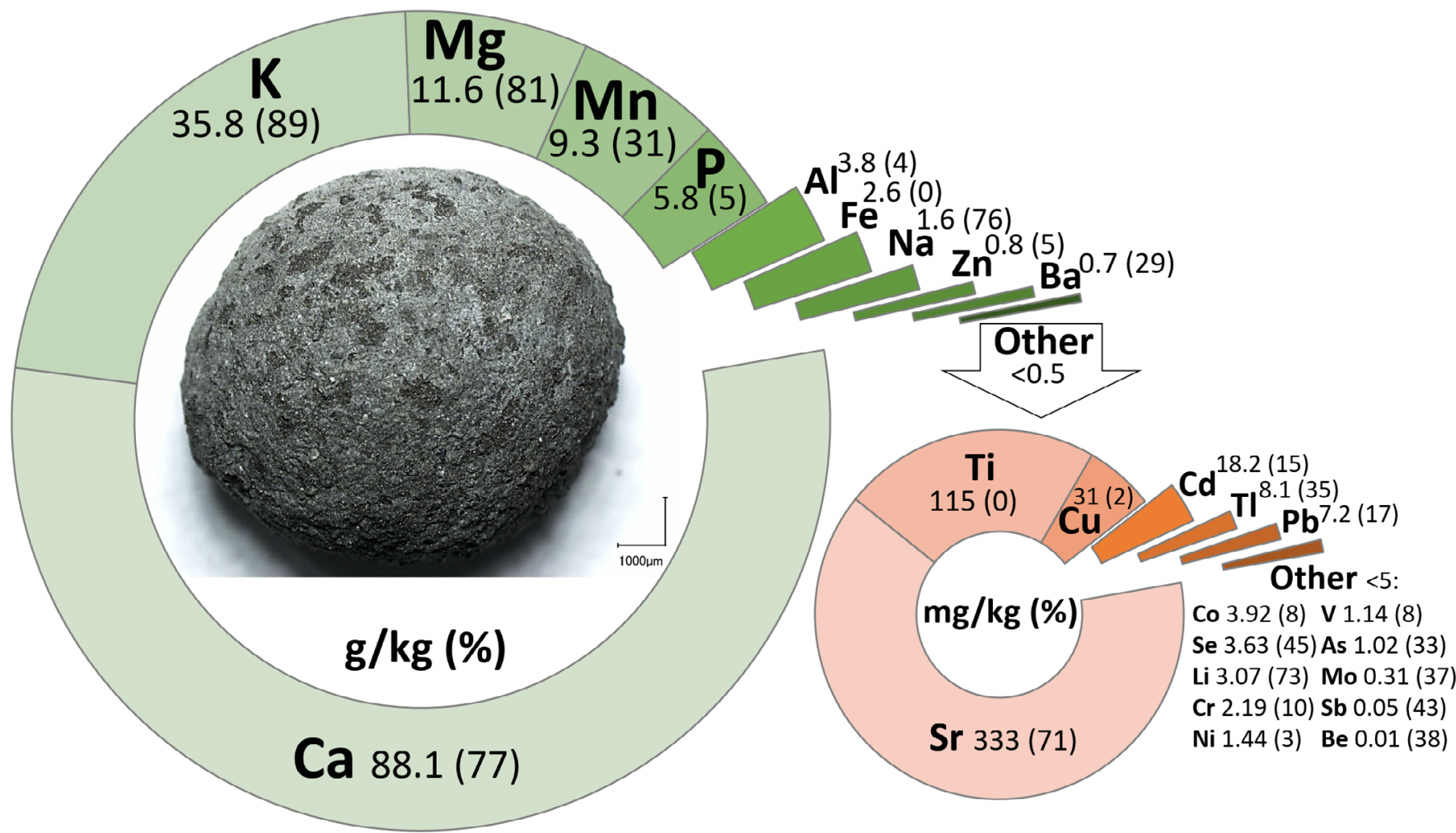

Figure 3: Total content and bioavailability (in brackets) of elements (indicating maximum detected values as a worst-case), and visualization of a spherical ash-sapropel granule.

potentially toxic elements preferably should be bound into insoluble compounds.

Regarding potentially toxic contaminants, quality provision requirements in Europe have been set specifically for bio-based soil improvers (EC,2018). In the final product, the content of the following chemical elements must not be exceeded (expressed as $\mathrm{mg} \mathrm{kg}^{-1}$ dry weight): Cd and $\mathrm{Hg}$ each $1 \mathrm{mg} \mathrm{kg}^{-1}, \mathrm{Mo} 2 \mathrm{mg} \mathrm{kg}^{-1}$, $\mathrm{Ni} 50 \mathrm{mg} \mathrm{kg}^{-1}, \mathrm{Cr}, \mathrm{Cu}$, and $\mathrm{Pb}$ each $100 \mathrm{mg} \mathrm{kg}{ }^{-1}$, Zn $300 \mathrm{mg} \mathrm{kg-1}$, and for products containing raw material from industrial processes Se $1.5 \mathrm{mg} \mathrm{kg}^{-1}$, As $10 \mathrm{mg} \mathrm{kg}^{-1}$ and $\mathrm{F} 200 \mathrm{mg} \mathrm{kg}{ }^{-1}$. Furthermore, the content of glass, metal, and plastic must be lower than $0.5 \%$ each and a product must not exceed the maximum levels of primary pathogens (Salmonella absent in $25 \mathrm{~g}$ of product, helminth ova absent in $1.5 \mathrm{~g}$ of product, $E$. coli $<1000 \mathrm{MPN} \mathrm{g}^{-1}$, where MPN - most probable number (EC, 2018). Nevertheless, these requirements may vary due to country-specific governmental regulations. Potentially toxic elements in elaborated ash-sapropel granules were detected at low concentrations, and their bioavailability was assessed as insignificant corresponding to the findings of other studies (Pesonen et al., 2017). However, the obtained maximum values (Figure 3) indicated that some elements might be of concern, i.e., the concentration of $\mathrm{Zn}, \mathrm{Se}$, and $\mathrm{Cd}$ in batch analyses can exceed those values set for bio-based soil improvers. However, it should be taken into account that the optimal application rate is relatively low and, therefore, adverse effects of potentially toxic elements in the environment would be unlikely. Plant response tests using fast-growing species such as Lactuca sativa L. revealed that the most optimal was the addition of $50 \mathrm{~g} \mathrm{~L}^{-1}$ of ash-sapropel granules; however, additional nutrient $(\mathrm{N}$ and $\mathrm{P})$ source is needed for better plant development. Therefore, this peat-free formulation for soil improvement is still in need of beneficial modifications.

The purity and safety of raw material and final product is an important question of concern in elaborating such products as peat-free soil amendments. The problem related to biomass used for energy production is its variable chemical composition that depends on various factors (e.g., plant species used, plant parts used, seasonality) and also affects generated waste ashes - utilized as a raw material (EC, 2018; Masto et al., 2015; Pesonen et al., 2017; Vincevica-Gaile et al., 2019). It results in problematic product validation and standardized quality assurance. The measures to monitor the concentration of elements of awareness involve batch analyses of raw material and the final product (EC, 2017; 2018). 
It was assessed that the elaborated peat-free soil amendment is applicable as a soil amendment at particular conditions, i.e., specifics of soil conditions should be taken into account. The formula can be used to improve the state of soils exposed to salinization at certain conditions, as well sapropel content in it may serve as a metal immobilizer. The formula itself is not a universal but specific soil amendment, and it can be upgraded to a more widely applicable product (e.g., peat-free substrate) when the development of the product is continued. However, the results indicated that adjusting other nutrients and $\mathrm{pH}$ is needed for a more optimal plant response, and it should be tested on various plant species. Therefore, the formula of peat-free soil conditioner preferably should be complemented sustainably by adding a natural source or secondary raw material rich in these essential nutrients, for example, by incorporating liquid manure, manure, slurry, compost, vermicompost, sapropel, or digestate.

\section{Conclusions and Recommendations}

Notwithstanding the broad availability of various materials, the way to sustainable peat-free soil amendments is obstacles covered. Several aspects have to be considered, such as the safety of materials (absence of chemical and biological hazardous components), chemical specification and composition, physical properties, material consistency, degradation potential, amount and seasonality of availability, etc. The complexity of peat-free soil amendment development involves its conformity to target functionality as it has to reconcile with soil-like texture and peat-like properties, as well as positive (or at least not adverse) effects on plant response.

The economically and environmentally justified choice of raw materials is one of the cornerstones in elaborating sustainable peat-free soil amendments. Locally available raw material should be considered as the most important source of possible ingredients. The case studies revealed the broad availability and appropriate utility of biomass ashes in soil improvement; however, their characteristic physicalchemical properties do not favor environmental awareness. Therefore, as a solution can be considered ash granulation with a natural binder. Peat-free soil amendment derived by granulation of energy production waste in a mixture with fresh organic-rich lake sediments presented as a case example is a step forward in sustainable material cycling; furthermore, extraction of freshwater sediments leads to expanded exploitation of local resources and prevention of lakes from overgrowth and extensive eutrophication. Derived granules are abundant in several elements (e.g., $\mathrm{Ca}, \mathrm{K}, \mathrm{Mg}, \mathrm{Mn}$ ) with variable bioavailability; however, essential nutrient ( $\mathrm{N}$ and $\mathrm{P}$ ) enrichment and $\mathrm{pH}$ adjustment might be needed for a more optimal plant response essentially significant for the application in agriculture.

It can be concluded that peat-free soil amendment elaboration can be better implemented on a regional scale after assessing agricultural needs, soil specifics, and improvement needs, as well as available raw material variety applicable as ingredients in soilimproving products.

\section{Acknowledgments}

This study was supported by project No.1.1.1.2/ VIAA/1/16/029 (Formula of peat-free soil conditioner with controlled-release fertilizing effect applicable for soil remediation and quality improvement of agricultural production; www.wise. lu.lv). The Indonesian experts in authorship are thankful for joint this research. Hopefully, peat-free soil amendments can increase the productivity of sustainable agriculture in Indonesia.

\section{Novelty Statement}

The novelty of this study is driven by the global trends to find new sustainable and renewable materials that can replace peat which is a fossil resource but used in vast amounts for gardening, agriculture, planting, horticulture worldwide. General features for peatfree soil-improving products are stated in the article as well as an example of product development from biomass ashes and sapropel is shortly described.

\section{Author's Contribution}

ZVG: Designed and implemented the study, elaborated the data analysis, performed literature search, and analysis, manuscript preparation and revision.

KS: Performed literature search and analysis, data tabulation and manuscript revision.

MK and DD: Elaborated the intellectual content and study supervision.

RHS: Performed literature search and analysis, data tabulation, manuscript format, manuscript review and manuscript revision.

PGA, MZM, LZ, AS and RA: Performed literature 
search and manuscript review.

JB and DHG: Performed literature search, manuscript review and guarantor.

All authors have read and approved the final manuscript.

\section{Conflict of interest}

The authors declare that there is no conflict of interest regarding the publication of this article.

\section{References}

Abdullah, K., A.S. Uyun, R. Soegeng, E. Suherman, H. Susanto, R.H. Setyobudi, J. Burlakovs and Z. Vincēviča-Gaile. 2020. Renewable energy technologies for economic development. E3S Web Conf. 188(00016): 1-8. https://doi. org/10.1051/e3sconf/202018800016

Adinurani, P.G., R.H. Setyobudi, S.K. Wahono, M. Maizirwan, A. Nindita, E. Purbajanti, S.S. Harsono, A.R. Malala, L.O. Nelwan and A. Sasmito. 2017. Ballast weight review of capsule husk Jatropha curcas Linn. on acid fermentation first stage in two-phase anaerobic digestion. Proc. Pak. Acad. Sci., B. 54 (1): 47-57.

Agusta, H., F.N. Nisya, R.N. Iman and S. Agustina. 2021. The application and effectiveness of fly ash granule using tapioca flour and sugarcane molasses as granule agents for soil ameliorant and fertilizer. IOP Conf. Ser. Earth Environ. Sci., 623(012063):1-4. https://doi. org/10.1088/1755-1315/623/1/012063

Anas, I., P.G. Adinurani and R.H Setyobudi. 2007. The role of bioethanol waste in making Mixed $\mathrm{G}$ fertilizer for increasing sugar productivity in sugar factories in PT Rajawali Nusantara Indonesia. 2007 National Conference Utilization of by-products of the biodiesel and ethanol industry as well as opportunities for the development of their integrated industry. Jakarta, 13 Maret 2007. (http://repository.ipb. ac.id/handle/123456789/41940)

Anggarani, B.O., R. Rasgianti, M. Triani and R.B. Sitanggang. 2021. The study of fly ash effect as fertilizer. IOP Conf. Ser.: Mater. Sci. Eng., 1098 (052019): 1-5. https://doi.org/10.1088/1757899X/1098/5/052019

Arfiana, E.R. Finalis, I. Noor, S.D.S. Murti, H. Suratno, E. Rosyadi, H. Saputra and R. Noda. 2021. Oil palm empty fruit bunch ash as a potassium source in the synthesis of NPK
fertilizer.IOP Conf.Ser.Earth Environ. Sci.,749 (012038): 1-9. https://doi.org/10.1088/17551315/749/1/012038

Atanu, M. and R. Lal. 2013. Biochar impacts on soil physical properties and greenhouse gas emissions. Agronomy, 3(2): 313-339. https:// doi.org/10.3390/agronomy3020313

Awasthi, A.K., V.R.S. Cheela, I. D'Adamo, E. Iacovidou, M.R. Islam, M. Johnson, T.R. Miller, K. Parajuly, A. Parchomenko, L. Radhakrishan, M. Zhao, C. Zhang and J. Li. 2021. Zero waste approach towards a sustainable waste management. Resour. Environ. Sustain., 3(100014):1-3. https://doi.org/10.1016/j. resenv.2021.100014

Bar-Tal, A., U.K. Saha, M. Raviv and M. Tuller. 2019. Inorganic and synthetic organic components of soilless culture and potting mixtures. p. 259-301. In: Michael, R., H. Lieth and A. Bar-Tal (eds), Soilless culture: Theory and practice: $2^{\text {nd }}$ edn. Elsevier, Amsterdam, Netherlands. https://doi.org/10.1016/B978-0444-63696-6.00007-4

Bhattacharya, S.S. and G.N. Chattopadhyay. 2002. Increasing bioavailability of phosphorus from fly ash through vermicomposting. J. Environ. Qual., 31:2116-2119. https://doi.org/10.2134/ jeq2002.2116

Brotodjojo, R.R.R. and A. Dyah. 2016. Effect of application of granular organic fertilizer enriched with boiler ash and neem leaves powder on plant resistance against insect pests. Int. J. Biosci. Biochem., 6 (4): 152-157. https:// doi.org/10.17706/ijbbb.2016.6.4.152-157

Carlile, W.R., C. Cattivello and P. Zaccheo. 2015. Organic growing media: Constituents and properties. Vadose Zone J., 14(6):1-13. https:// doi.org/10.2136/vzj2014.09.0125

Chirenje, T. and L.Q. Ma. 2002. Impact of highvolume wood-fired boiler ash amendment on soil properties and nutrients. Commun. Soil Sci. Plant Anal., 33(1-2):1-17. https://doi. org/10.1081/CSS-120002373

Chojnacka, K., K. Moustakas and A. WitekKrowiak. 2020. Bio-based fertilizers: A practical approach towards circular economy. Bioresour. Technol., 295(122223):1-11. https://doi. org/10.1016/j.biortech.2019.122223

Coenen,L.,J.Moodysson and H.Martin.2015.Path renewal in old industrial regions: Possibilities and limitations for regional innovation policy. 
Reg. Stud., 49(5):850-865. https://doi.org/10. 1080/00343404.2014.979321

De Simone, V., D. Caccavo, G. Lamberti, M. d'Amore and A.A. Barba. 2018. Wetgranulation process: Phenomenological analysis and process parameters optimization. Powder Technol., 340:411-419. https://doi. org/10.1016/j.powtec.2018.09.053

Deenik, J.L., D. Aminata, U. Goro, S. Campbell, Y. Sumiyoshi. M.J. Antal. 2011. Charcoal ash and volatile matter effects on soil properties and plant growth in an acid ultisol. Soil Sci., 176(7): 336-345. https://doi.org/10.1097/ SS.0b013e31821fbfea

Demeyer, A., N.J.C. Voundi and M.G. Verloo. 2001. Characteristics of wood ash and influence on soil properties and nutrient uptake: An overview. Bioresour. Technol., 77:287-295. https://doi. org/10.1016/S0960-8524(00)00043-2

Dirbeba, M.J. A. Aho, N. DeMartini, A. Brink, I. Mattsson, L. Hupa and M. Hupa. 2019a. Fast pyrolysis of dried sugar cane vinasse at 400 and $500{ }^{\circ} \mathrm{C}$ : Product distribution and yield. Energy Fuels, 33(2): 236-1247. https://doi. org/10.1021/acs.energyfuels.8b03757

Dirbeba M.J., A.Brink, M. Zevenhoven, N. De Martini, D. Lindberg, L. Hupa and M. Hupa. 2019b. Characterization of vinasse for thermochemical conversion-fuel fractionation, release of inorganics, and ash-melting behaviour. Energy Fuels, 33(7): 5840-5848. https://doi. org/10.1021/acs.energyfuels.8b04177

EC. 2017. EU Ecolabel growing media, soil improvers and mulch. User manual V1.4. European Commission (EC), Brussels, Belgium. https://ec.europa.eu/environment/ ecolabel/documents/gmsim/user_manual.pdf

EC. 2018. Factsheet bio-based soil improvers. European Commission (EC), Brussels, Belgium.

EC. 2019. Communication on the European Green Deal. European Commission (EC), Brussels, Belgium. https://www.coleurope.eu/europeangreen-deal

EUBIA. 2021. Bio-based soil improvers. European Biomass Industry Association (EUBIA), Brussels, Belgium. https://www.eubia.org/cms/ wiki-biomass/bio-based-products/bio-basedsoil-improvers/

Ghadeer I.O. and S.I. AlKhalil. 2019. A study of the environmental impacts of the Gishori industrial complex on plant diversity in Tulkarm, Palestine. Jordan J. Biol. Sci., 12(4): 487-494.

Green, D.W. and M.Z. Southard 2019. Perry's chemical engineers' handbook: 9th edn. McGraw-Hill Education, New York, USA.

Gruda, N.S. 2019. Increasing sustainability of growing media constituents and stand-alone substrates in soilless culture systems. Agronomy. 9(298):1-24.

https://doi.org/10.3390/ agronomy 9060298

Guillaume, T., A.M. Holtkamp, M. Damris, B. Brümmer, and Y. Kuzyakov. 2016. Soil degradation in oil palm and rubber plantations under land resource scarcity. Agric. Ecosyst. Environ., 232:110-118. https://doi. org/10.1016/j.agee.2016.07.002

Gurgel, M.N.D.A., S.T.R. Correa, D.D. Neto and D.R. De Paula Júnior. 2015. Technology for sugarcane agroindustry waste reuse as granulated organomineral fertilizer. Eng. Agríc. 35(1):63-75. https://doi.org/10.1590/18094430-Eng.Agric.v35n1p63-75/2015

Hartemink, A.E. 1964. Soil fertility decline in the tropics: With case studies on plantations. Cabi Publishing, London, UK.

Herry, P.B.O., A. Dermawan, Q.P. Ilham, P. Pacheco, F. Nurfatriani, E. Suhendang. 2020. Reconciling oil palm economic development and environmental conservation in Indonesia: A value chain dynamic approach. For Policy Econ., 111(102089):1-12. https://doi. org/10.1016/j.forpol.2020.102089

Hsiao-Hang, T., E.M. Slade, K.J. Willis, J.P. Caliman, J.L. Snaddon. 2016. Effects of soil management practices on soil fauna feeding activity in an Indonesian oil palm plantation. Agric. Ecosyst. Environ., 218:133-140. https:// doi.org/10.1016/j.agee.2015.11.012

Index Mundi. 2013. Peat production by country. (https://www.indexmundi.com/ minerals/?product=peat\&graph=production)

Jain, A., S. Sarsaiya, M.K. Awasthi, R. Singh, R. Rajput, U.C. Mishra, J. Chen and J. Shi. 2021. Bioenergy and bio-products from bio-waste and its associated modern circular economy: Current research trends, challenges, and future outlooks. Fuel. 307(121859):1-13. https://doi. org/10.1016/j.fuel.2021.121859

Jürgen, K., P.Tammeorg,M. Shanskiy, R. Sakrabani, 
H. Knicker, C. Kammann, E.M. Tuhkanen, G. Smidt, M. Prasad, K. Tiilikkala, S. Sohi, G. Gascó, C. Steiner and B. Glaser. 2017. Synergistic use of peat and charred material in growing media - an option to reduce the pressure on peatlands? J. Environ. Eng. Landsc. Manag., 25(2): 160-174. https://doi.org/10.384 6/16486897.2017.1284665

Kamalia, N., A.R. Mehrabadi, M. Mirabi and M.A. Zahed. 2021. Comparison of micro and nano $\mathrm{MgO}$-functionalized vinasse biochar in phosphate removal: Micro-nano particle development, RSM optimization, and potential fertilizer J. Water Process. Eng., 39:101741. https://doi.org/10.1016/j.jwpe.2020.101741

Kamman, C., J. Ippolito, N. Hagemann, N. Borchard, M.L. Cayuela, J.M. Estavillo, T. Fuertes-Mendizabal, S. Jeffery, J. Kern, J. Novak, D. Rasse, S. Saarnio, H.-P. Schmidt, K. Spokas and N. Wrage-Mönnig. 2017. Biochar as a tool to reduce the agricultural greenhousegas burden - knowns, unknowns and future research needs. J. Environ. Eng. Landsc. Manag., 25(2):114-139. https://doi.org/10.384 6/16486897.2017.1319375

Klavins, M. and V. Obuka. 2018. Local knowledge and resources as driving forces of sustainable bioeconomy. p. 173-186. In: Walter, L.F., D.M. Pociovălișteanu,P.R. Borges de Brito and I.B. de Lima (eds), Towards a sustainable bioeconomy: Principles, challenges and perspectives. Springer Nature, Switzerland. https://doi. org/10.1007/978-3-319-73028-8_10

Kusumaningtyas, R.D., Oktafiani, D. Hartanto, P.A. Handayani, D.R.A. Muhammad. 2015. Manufacture of solid organo-mineral Fertilizer (OMF) from industrial waste bioethanol (vinasse). J. Bahan Alam Terbarukan, 4 (2): 46-54.

Kusumaningtyas, R.D., O. Oktafiani, D. Hartanto, P.A. Handayani. 2017. Effects of solid vinassebased organic fertilizer on some growth indices of tomato plant. J. Bahan Alam Terbarukan, 6(20): 190-197. https://doi.org/10.15294/jbat. v6i2.12507

Kusumaningtyas, R.D.,D.Hartanto,H.A.Rohman, Mitamaytawati, N. Qudus, and Daniyanto. 2020. Valorization of sugarcane-base bioethanol industry waste (vinasse) to organic fertilizer. p. 203-224. In: Zakaria, Z.A., C.N. Aguilar, R.D Kusumaningtyas, P. Binod (eds), Valorisation of agro-industrial residues - volume II: Nonbiological approaches. Springer Nature. Switzerland. https://doi.org/10.1007/978-3030-39208-6_10

Kusumawati, A., E. Hanudin, B.H. Purwanto and M. Nurudin. 2020. Composition of organic C fractions in soils of different texture affected by sugarcane monoculture. Soil Sci. Plant Nutr., 66(1):206-213. https://doi.org/10.1080/00380 768.2019 .1705740

Marcílio, N.D.A. Gurgel, S.T.R. Correa, D.D. Neto and D.R. De Paula Júnior. 2015. Technology for sugarcane agroindustry waste reuse as granulated organomineral fertilizer. Engenharia Agrícola, 35(1):63-75. https://doi.org/10.1590/18094430-Eng.Agric.v35n1p63-75/2015

Martinsen, V., V.Alling, N.L. Nurida,J.Mulder,S.E. Hale, C. Ritz, D.W. Rutherford, A. Heikens, G.D. Breedveld and G. Cornelissen. 2015. pH effects of the addition of three biochars to acidic Indonesian mineral soils. Soil Sci. Plant Nutr., 61(5): 821-834. https://doi.org/10.1080/00380 768.2015.1052985

Masto, R.E., E. Sarkar, J. George, K. Jyoti, P. Dutta and L.C.Ram.2015. PAHs and potentially toxic elements in the fly ash and bed ash of biomass fired power plants. Fuel Process. Technol., 132:139-152. https://doi.org/10.1016/j. fuproc.2014.12.036

Millar, N., E. McLaughlin and T. Börger. 2019. The circular economy: Swings and roundabouts? Ecol. Econ., 158:11-19. https:// doi.org/10.1016/j.ecolecon.2018.12.012

Mohamed, S.A., A.A. Abdelwahab, E.H. E1Bialy and I.G. El-Sayed. 2016. Vegetation-soil relationships in wadi El-Rayan protected area, western desert, Egypt. Jordan J. Biol. Sci., 9(2): 97-107.

Molindo. 2021. Molindo, the largest manufacturer in Indonesia of high quality food grade ethanol and liquid $\mathrm{CO}_{2}$. Jakarta, Indonesia (https:// molindo.co.id/en/).

Nizami, A., J. Ali and M. Zulfiqar. 2020. Climate change is real and relevant for sustainable development, an empirical evidence on scenarios from North-West Pakistan. Sarhad J. Agric. 36(1):42-69. https://doi.org/10.17582/ journal.sja/2020/36.1.42.69

Nur, H.H., O.H. Ahmed, L. Omar and H.Y. Ch'ng. 2021. Soil nitrogen sorption using charcoal and wood ash. Agronomy, 11(9): 1801:1-34. https:// 
doi.org/10.3390/agronomy11091801

Nurzakiah, S., F. Agus and H. Syahbuddin. 2013. Ameliorant application on variation of carbon stock and ash content on peatland South Kalimantan. J. Trop. Soils, 18 (1): 11-16. https://doi.org/10.5400/jts.2013.18.1.11

Omil, B., V. Piñeiro and A. Merino. 2013. Soil and tree responses to the application of wood ash containing charcoal in two soils with contrasting properties. Forest Ecol. Manag., 295:199-212. https://doi.org/10.1016/j.foreco.2013.01.024

Osaki, M., D. Nursyamsi, M. Noor, H. Wahyunto and H. Segah . 2016. Peatland in Indonesia. p. 49-58. In: Osaki M. and N.Tsuji (eds), Tropical Peatland Ecosystems. Springer, Tokyo. https:// doi.org/10.1007/978-4-431-55681-7_3

Perkiömäki, J. 2004. Wood ash use in coniferous forests. A soil microbiological study into the potential risk of cadmium release. $\mathrm{PhD}$ dissertation, University of Helsinki, Helsinki, Finland.

Pesonen, J., T. Kuokkanen, P. Rautio and U. Lassi. 2017. Bioavailability of nutrients and harmful elements in ash fertilizers: Effect of granulation. Biomass Bioenerg., 100:92-97. https://doi. org/10.1016/j.biombioe.2017.03.019

Petrenko, C., J. Paltseva and S. Searle. 2016. Ecological impacts of palm oil expansion in Indonesia. International Council on Clean Transportation, Washington, USA. (https:// theicct.org/sites/default/files/publications/ Indonesia-palm-oil-expansion_ICCT_ july2016.pdf)

Prisca, D.J., O.H. Ahmed, L. Omar and N.A. Hasbullah. 2021. Phosphorus transformation in soils following co-application of charcoal and wood ash. Agronomy, 11(10): 1-25. https://doi. org/10.3390/agronomy11102010

Pursula, T., M. Aho, I. Rönnlund and M. Päällysaho. 2018. Environmental sustainability indicators for the bioeconomy. p. 43-61. In: Walter, L.F., D.M. Pociovălișteanu, P.R. Borges de Brito and I.B. de Lima (eds), Towards a sustainable bioeconomy: Principles, challenges and perspectives. Springer Nature, Switzerland. https://doi.org/10.1007/978-3-319-730288_3

Putra, R.P., M.R.R. Ranomahera, M.S. Rizaludin., R. Supriyanto and V.A.K. Dewi. 2020. Investigating environmental impacts of longterm monoculture of sugarcane farming in Indonesia through DPSIR framework. Biodiversitas, 21(10): 4945-4958. https://doi. org/10.13057/biodiv/d211061

Puvan, P., O.H. Ahmed, L. Omar, H.Y. Ch'ng, P.D. Johan and N.H. Hamidi. 2021. Co-application of charcoal and wood ash to improve potassium availability in tropical mineral acid soils. Agronomy, 11(10): 2081:1-30. https://doi. org/10.3390/agronomy11102081

Quintero, R.R., E. Garbarino, H. Saveyn and O. Wolf. 2015. Revision of the EU ecolabel criteria for soil improvers and growing media. Joint Research Centre, Ispra, Italy.

Ram, L.C. and R.E. Masto. 2014. Fly ash for soil amelioration: A review on the influence of ash blending with inorganic and organic amendments,Earth Sci.Rev.,128:52-74.https:// doi.org/10.1016/j.earscirev.2013.10.003

Rieley J. and S. Page. 2016. Tropical peatland of the world. p 3-32. In: Osaki M. and N. Tsuji (eds), Tropical Peatland Ecosystems. Springer, Tokyo. https://doi.org/10.1007/978-4-431-556817_1

Reginald, E.M., E. Sarkar, J. George, K. Jyoti, P. Dutta and L. C. Ram. 2015. PAHs and potentially toxic elements in the fly ash and bed ash of biomass fired power plants. Fuel Process. Technol., 132: 139-152. https://doi. org/10.1016/j.fuproc.2014.12.036

Rodrigues, R.F., S.R.Leite, D.A.Santos and M.A.S Barrozo. 2017. Drum granulation of single super phosphate fertilizer: Effect of process variables and optimization. Powder Technol., 321:251-258. https://doi.org/10.1016/j. powtec.2017.08.036

Romdhane, L., L.B. Ebinezer, A. Panozzo, G. Barion, C.D. Cortivo, L. Radhouane and T. Vamerali. 2021. Effects of soil amendment with wood ash on transpiration, growth, and metal uptake in two contrasting maize (Zea mays L.) hybrids to drought tolerance. Front. Plant Sci., 12:661909. https://doi.org/10.3389/ fpls.2021.661909

Röser,D.,A.Asikainen, K. Raulund-Rasmussen and I. Stupak (eds). 2008. Sustainable use of forest biomass for energy. A synthesis with focus on the Baltic and Nordic Region. Springer Nature, Switzerland. https://doi.org/10.1007/978-14020-5054-1

Sadik, M.W., M.M. Zohair, A.A. El-Beih, E.R. Hamed and M.Z. Sedik. 2021. Utilization of 
agro-industrial wastes as carbon source in solidstate fermentation processes for the production of value-added byproducts. Jordan J. Biol. Sci., 14(1): 157 - 161.

Sadiq, S., A. Saboor, F. Jamshaid, A.Q. Mohsin and A. Khalid. 2019. Assessment of farmers' vulnerability to climate change in agro-climatic zones of Pakistan: An index based approach. Sarhad J. Agric . 35(3):734-740. https://doi. org/10.17582/journal.sja/2019/35.3.734.740

Samadhi, T.W., W. Wulandari, R. A. Amalia and R. Khairunnisah. 2019. Potassium recovery from tropical biomass ash. AIP Conf Proc., 2085: 020003. https://doi.org/10.1063/1.5094981

Santalla, M., B. Omil, R. Rodríguez-Soalleiro and A. Merino. 2011. Effectiveness of wood ash containing charcoal as a fertilizer for a forest plantation in a temperate region. Plant Soil, 346: 63-78. https://doi.org/10.1007/s11104011-0794-y

Schiefer, J., G.J. Lair and W.E.H. Blum. 2016. Potentialandlimits ofland and soilfor sustainable intensification of European agriculture. Agric. Ecosyst. Environ., 230:283-293. https://doi. org/10.1016/j.agee.2016.06.021

Schmilewski, G. 2009. Growing medium constituents used in the EU. Acta Hortic. 819:33-46. https://doi.org/10.17660/ ActaHortic.2009.819.3

Setyobudi, R.H., S.K. Wahono, P.G. Adinurani, A. Wahyudi,W.Widodo, M.Mel, Y.A Nugroho, B. Prabowo and T. Liwang. 2018. Characterisation of arabica coffee pulp - hay from Kintamani Bali as prospective biogas feedstocks. MATEC Web Conf. 164 (01039): 1-13. https://doi. org/10.1051/matecconf/201816401039

Setyobudi, R.H., L. Zalizar, S. K. Wahono, W. Widodo, A. Wahyudi, M. Mel, B. Prabowo, Y. Jani, Y.A. Nugroho, T. Liwang and A. Zaebudin. 2019. Prospect of Fe non-heme on coffee flour made from solid coffee waste: Mini review. IOP Conf. Ser. Earth Environ. Sci., 293 (012035):1-24. https://doi.org/10.1088/17551315/293/1/012035

Setyobudi, R.H., E. Yandri, M.F.M. Atoum, S.M. Nur, I. Zekker, R. Idroes, T.E. Tallei, P.G. Adinurani, Z. Vincēviča-Gaile, W. Widodo, L. Zalizar, N. Van Minh, H. Susanto, R.K. Mahaswa, Y.A. Nugroho, S.K. Wahono and Z. Zahriah. 2021. Healthy-smart concept as standard design of kitchen waste biogas digester for urban households. Jordan J. Biol. Sci., 14(3):613-620. https://doi.org/10.54319/ jjbs/140331

Shah. M.A.A., M. Mohsin, C. Chesneau, A. Zulfiqar, F. Jamal, K. Nadeem and R.A.K. Sherwani. 2021. Analysis of factors affecting yield of agricultural crops in Bahawalpur District: Analysis of factors of major agricultural crops. Proc. Pak. Acad. Sci. 57(4): 99-112.

Shahputra, M.A. and Z. Zen. 2018. Positive and negative impacts of oil palm expansion in Indonesia and the prospect to achieve sustainable palm oil. IOP Conf. Ser. Earth Environ. Sci., 122 (012008): 1-7. https://doi. org/10.1088/1755-1315/122/1/012008

Shishkin, A., V. Laksa, Z. Shidlovska, H. Timermane, H. Aguedal, V. Mironov and J. Ozolins. 2017. Illite clay ceramic hollow sphere - obtaining and properties. Key Eng. Mater., 721:316-321. https://doi.org/10.4028/www. scientific.net/KEM.721.316

Sparrevik, M., H. Lindhjem, V. Andria, A.M. Fet and G. Cornelissen. 2014. Environmental and socioeconomic impacts of utilizing waste for biochar in rural areas in Indonesia - a systems perspective. Environ. Sci. Technol., 48(9):46644671. https://doi.org/10.1021/es405190q

Stankevica, K., J. Burlakovs and M. Klavins. 2013. Organic rich freshwater sediments (sapropel) as potential soil amendment for recultivation of areas contaminated with heavy metals. 13th SGEM GeoConference on Water Resources. Forest, Marine and Ocean Ecosystems, SGEM2013 Conference Proceedings, p 595602. https://doi.org/10.5593/SGEM2013/ BC3/S13.016

Stankeviča, K. 2020. Character of sapropel properties based on its formation conditions and possibilities of its use. PhD Thesis, University of Latvia,Riga,Latvia.https://dspace.lu.lv/dspace/ bitstream/handle/7/53296/PhD_Thesis_ STANKEVICA.pdf? sequence $=5$ \&isAllowed $=y$ Stankevica, K., Z. Vincevica-Gaile, M. Klavins, L. Kalnina, N. Stivrins, I. Grudzinska and E. Kaup. 2020. Accumulation of metals and changes in composition of freshwater lake organic sediments during the Holocene. Chem. Geol., 539:119502. https://doi.org/10.1016/j. chemgeo.2020.119502

Tanneberger, F., C. Tegetmeyer, S. Busse, A. BarthelmesS. Shumka, A. Moles Mariné, K. 
Jenderedjian, G.M. Steiner, F. Essl, J. Etzold, C. Mendes, A. Kozulin, P. Frankard, Đ. Milanović, A. Ganeva, I. Apostolova, A. Alegro, P. Delipetrou, J. Navrátilová, M. Risager, A. Leivits, A.M. Fosaa, S. Tuominen, F. Muller, T. Bakuradze, M. Sommer, K. Christanis, E. Szurdoki, H. Oskarsson, S.H. Brink, J. Connolly, L. Bragazza, G. Martinelli, O. Aleksāns, A. Priede, D. Sungaila, L. Melovski, T. Belous, D. Saveljić, F. de Vries, A. Moen, W. Dembek, J. Mateus, J. Hanganu, A. Sirin, A. Markina, M. Napreenko, P. Lazarević, V. Šefferová Stanová, P. Skoberne, P. Heras Pérez, X. PontevedraPombal, J. Lonnstad, M. Küchler, C. WüstGalley, S. Kirca, O. Mykytiuk, R. Lindsay, and H. Joosten. 2017. The peatland map of Europe. Mires Peat. 19(22):1-17.

Taparia, T., E.Hendrix, E. Nijhuis, W. de Boer and J. van der Wolf. 2021. Circular alternatives to peat in growing media: A microbiome perspective. J. Clean. Prod. 327(129375):1-16. https://doi. org/10.1016/j.jclepro.2021.129375

Thomas, G., A.M. Holtkamp, M. Damris, B. Brümmer and Y. Kuzyakov. 2016. Soil degradation in oil palm and rubber plantations under land resource scarcity. Agric. Ecosyst. Environ., 232: 110-118. https://doi. org/10.1016/j.agee.2016.07.002

Titiek I., B. Guritno, N. Basuki and A. Suryanto. 2011. Biochar for sustaining productivity of cassava based cropping systems in the degraded lands of East Java, Indonesia. J. Trop. Agric., 49 (1-2) : 40-46.

Urbinati, A., D. Chiaroni and V. Chiesa. 2017. Towards a new taxonomy of circular economy business models J. Clean. Prod. 168:487-498. https://doi.org/10.1016/j.jclepro.2017.09.047

Utami, S.W., R.A.P. Tarigan and B. Widianingsih. 2019. Characterization of micronutrient and heavy metal content in organic fertilizers made from fly ash and organic waste. J Trop. Soils, 24(1): 11-16. https://doi.org/10.5400/jts.2019. v24i1.11-16

Vanham, D., L. Alfieri, M. Flörke, S. Grimaldi, V.Lorini, A. de Roo and L. Feyen. 2021. The number of people exposed to water stress in relation to how much water is reserved for the environment: a global modelling study. Lancet Planet. Health, 5(11):e766-e774. https://doi. org/10.1016/S2542-5196(21)00234-5

Vincevica-Gaile, Z. and K. Stankevica. 2018.
Impact of micro and macroelement content on potential use of freshwater sediments (gyttja) derived from lakes of eastern Latvia. Environ. Geochem. Health, 40(5):1725-1738. https:// doi.org/10.1007/s10653-017-9912-y

Vincevica-Gaile, Z., K. Stankevica, K. Irtiseva, A. Shishkin, V. Obuka, S. Celma, J. Ozolins and M. Klavins. 2019. Granulation of fly ash and biochar with organic lake sediments - A way to sustainable utilization of waste from bioenergy production. Biomass Bioenerg., 125:23-33. https://doi.org/10.1016/j. biombioe.2019.04.004

Vincevica-Gaile, Z., K. Stankevica, M. Klavins and A. Trubaca-Boginska. 2021a. Data on physical and chemical characterization of wood combustion products derived at cogeneration power plants. Data Brief., 36(106994):1-10. https://doi.org/10.1016/j.dib.2021.106994

Vincevica-Gaile Z., T. Teppand, M. Kriipsalu, M. Krievans,Y. Jani, M. Klavins, R.H. Setyobudi, I. Grinfelde, V. Rudovica,T. Tamm, M. Shanskiy, E. Saaremae, I. Zekker and J. Burlakovs. 2021b. Towards sustainable soil stabilization in peatlands: Secondary raw materials as an alternative. Sustainability, 13(12)-6726: 1-24. https://doi.org/10.3390/su13126726

Xu, J., P.J. Morris, J. Liu and J. Holden. 2018. PEATMAP: Refining estimates of global peatland distribution based on a metaanalysis. CATENA. 160:134-140. https://doi. org/10.1016/j.catena.2017.09.010

Yandri, E., B. Novianto., F. Fridolini., R.H. Setyobudi., H. Wibowo., S.K. Wahono., K. Abdullah., W. Purba and Y.A. Nugroho. 2021. The technical design concept of hi-tech cook stove for urban communities using non-wood agricultural waste as fuel sources. E3S Web of Conf. 226(00015):1-9(2021). https://doi. org/10.1051/e3sconf/202122600015

Zaffar, M., M. Jamil., G.H. Abassi., M. Nafees., M. Rafey and M. Kamran. 2017. Biochar and fly ash role in improving mechanical and physical properties of vertisol. Sarhad J. Agric, 33(1):151-161. https://doi.org/10.17582/ journal.sja/2017.33.1.151.161

Zakaria,Z.A., C.N. Aguilar, R.D. Kusumaningtyas, P. Binod (eds). 2020. Valorisation of agroindustrial residues - volume II: Non-biological approaches. Springer Nature. Switzerland. https://doi.org/10.1007/978-3-030-39208-6 